\title{
Comparison of adsorption affinity of anionic and cationic polyacrylamides for montmorillonite surface in the presence of chromium $(\mathrm{VI})$ ions
}

\author{
Małgorzata Wiśniewska ${ }^{1}$ (1) Gracja Fijałkowska ${ }^{1} \cdot$ Katarzyna Szewczuk-Karpisz $^{2} \cdot$ Teresa Urban $^{1}$. \\ Agnieszka Nosal-Wiercińska ${ }^{3} \cdot$ Grzegorz Wójcik $^{4}$
}

Received: 19 October 2018 / Revised: 21 November 2018 / Accepted: 28 November 2018 / Published online: 1 December 2018

(c) The Author(s) 2018

\begin{abstract}
Erosion, which is considered to be global problem, is the process of soil environment degradation due to the impact of wind (soil blowing, deflation) and water (soil washing, deep erosion). This leads to destruction of its structure, nutrients removal and finally bedrock exposition and desertification. One of the ways to prevent this phenomenon is the soil conditioners usage. These substances, also called soil flocculants, are macromolecular compounds which contribute to the reinforcement of soil structure as a result of its adsorption on the mineral surface. The soil conditioners commonly used in agriculture is ionic polyacrylamide (PAM) - both anionic and cationic. These macromolecular substances affect soil surface properties and adsorption behaviour of substances present in the environment-nutrients, organic molecules and also hazardous compounds as well as toxic heavy metals (i.e. chromium(VI) ions). The aim of this study was to investigate the impact of solution $\mathrm{pH}$, type of ionic groups in the polyacrylamide macromolecules and chromium(VI) ion concentration on the adsorption mechanism of $\mathrm{Cr}(\mathrm{VI})$ and PAM on the montmorillonite surface. The adsorption and electrokinetic properties of the montmorillonite-AN PAM or CT PAM/Cr(VI) systems were examined by means of spectrophotometry, potentiometric titration, SEM, XRD and DRS methods. It was shown that in the adsorbed layer composed of PAM-Cr(VI) complexes reduction of $\mathrm{Cr}(\mathrm{VI})$ to $\mathrm{Cr}(\mathrm{III})$ takes place.
\end{abstract}

Keywords Montmorillonite $\cdot$ Ionic polyacrylamide $\cdot \mathrm{PAM}$ adsorption $\cdot \mathrm{Cr}(\mathrm{VI})$ reduction $\cdot \mathrm{PAM}-\mathrm{Cr}(\mathrm{VI})$ complexes . Intercalation

\section{Introduction}

Dispersed colloidal particles of various minerals form the so-called soil sorption complex. Silicates and products of their transformation-aluminosilicates form the main

Małgorzata Wiśniewska

wisniewska@hektor.umcs.lublin.pl

1 Department of Radiochemistry and Colloids Chemistry, Faculty of Chemistry, Maria Curie- Sklodowska University, M. Curie-Sklodowska Sq. 3, 20-031 Lublin, Poland

2 Institute of Agrophysics, Polish Academy of Sciences, Doswiadczalna Street 4, 20-290 Lublin, Poland

3 Department of Analytical Chemistry and Instrumental Analysis, Faculty of Chemistry, Maria Curie-Sklodowska University, M. Curie-Sklodowska Sq. 3, 20-031 Lublin, Poland

4 Department of Inorganic Chemistry, Faculty of Chemistry, Maria Curie- Sklodowska University, M. Curie-Sklodowska Sq. 3, 20-031 Lublin, Poland mineral component of soils. They are formed as a result of silicon, oxygen, metal ions, as well as water molecules binding. The structural unit of silicates is the silicate anion$\mathrm{SiO}_{4}{ }^{4-}$ (Handke 2005; Sarbak 2009) A characteristic property of these minerals is the ability to exchange silicon atoms for aluminum ones in their crystal networks. As a result of this isomorphic substitution, minerals with an aluminum atom in the center of the tetrahedron (aluminosilicates) are created. Clay minerals which are hydrated aluminosilicates have a characteristic layered structure. Depending on the relative location of tetrahedral and octahedral units these minerals can be divided into the layered 2:1, 1:1 or amorphous aluminosilicates (Kunert and Zaborski 2006). 
Montmorillonite is a representative of the layered 2:1 clay mineral with one alumina octahedral sheet sandwiched between two silica tetrahedral sheets (Kurleto at al. 2015, Mikuła and Łach 2002; Kacperski 2002). A small electric charge in the structure of 2:1 clay minerals (mainly between layers) is compensated by the so-called inter-layered cations (e.g. hydrogen, sodium, calcium or magnesium cations). A characteristic feature of three-layered aluminosilicates is the ability to absorb water molecules or organic compounds, as well as the capability of ion exchange. These properties are due to the presence of weak van der Waals forces between packages. Absorption of molecules or ions, also known as intercalation, causes the expansion of the space between the silica and alumina sheets. This phenomenon also known as intercalation can be affected by many factors such as pressure, temperature or humidity of the environment, as well as intercalate concentration and structure (Sarbak 2010; Olejnik 2008; Natkański et al. 2012; Uddin 2017; Zhu et al. 2016).

Soils rich in aluminosilicate fractions such as montmorillonite, are naturally exposed to degrading factors such as wind or water. They can cause erosion, involving the destruction of soil structure and reduction of its fertility. This leads to environment destruction and soil nutrients removal, the bedrock exposition and desertification (Bronick and Lal 2005; Sojka et al. 2007; Lee et al. 2013) One of the ways to prevent soil erosion is the addition of soil conditioners (e.g. polyacrylamide or poly(acrylic acid)). These substances promote strengthening of the structure and stability of the soil by the flocculation phenomenon. Soil flocculants are macromolecular compounds which can bind loose mineral particles into larger aggregates by the polymer bridges formation between them (Mclaughlin and Bartholomew 2007; Basaran and Tasdemir 2014; Graveling et al. 1997; Lee and Schlautman 2015; Deng et al. 2006; Guezennec et al. 2015; He et al. 2017). Moreover, water and air relations or soil structure improvement in the presence of soil conditioners are observed. The presence of polymer affects the increase of water infiltration into the soil and can affect changes in surface properties of mineral particles (i.e. behaviour of nutrients, toxic heavy metals, organic substances present in the environment) (Mamedov et al. 2010; Green et al. 2004; Ajwa and Trout 2006; Wang et al. 2016; Lee et al. 2014; Ben-Hur and Keren 1997).

Environmental pollution with heavy metals has increased with the development of civilization. The main sources of environmental contamination are industrial wastes and sewages, metallurgical and chemical industry, mining or transport emissions. Also mineral fertilizers and products for plant protection can contribute to pollution of soil and water (Ociepa-Kubicka and Ociepa 2012; Sas-Nowosielska 2009, Vasquez-Murrieta et al. 2006). The concentration of heavy metals in the environment can be various and depends on their physicochemical properties and the ability to form soluble complexes (Nosal-Wiercińska and Dalmata 2002; Nosal-Wiercińska 2014; Grochowski et al. 2016). Depending on type, chemical form or dosage heavy metals can have a stimulating or negative effect on the living organisms. The elements such as $\mathrm{Fe}, \mathrm{Mn}, \mathrm{Cu}, \mathrm{Mo}, \mathrm{Zn}$ are the examples of metals which in a low amount are necessary for the proper course of metabolic processes, and in a greater concentration have harmful and toxic effects (Wang et al. 2003; Kowalski 1994; Devi and Fingermann 1995; Quek et al. 1998, Pueyo et al. 2004; Wójcik et al. 2004).

Chromium is one of the heavy metals. In nature this element has two stable oxidation levels and occurs as $\mathrm{Cr}$ (III) and $\mathrm{Cr}(\mathrm{VI})$. However, physicochemical properties and toxicity of these forms are different. Chromium(III) plays a key role in the metabolism of glucose and certain fats as well as proteins in mammals. Because of its strong oxidative properties chromium(VI) causes oxidation of unsaturated bonds in proteins (including enzymes), fatty and nucleic acids. This heavy metal ion shows high toxicity (i.e. mutagenic, carcinogenic and teratogenic properties) to humans, animals and plants. Damage of photosynthetic apparatus or gastrointestinal tract, skin changes and allergies are caused by chromium(VI) (Szymański 2009; Karthikeyan et al. 2005; Stearns et al. 1995; Ociepa-Kubicka and Ociepa 2012; Hadjispyrou et al. 2001; Zhang et al. 2012).

The main aim of the present study is the comparison of adsorption mechanism of two forms of ionic polyacrylamide (anionic and cationic) on the montmorylonite surface. The efficiency of chromium(VI) ions accumulation in the polymeric adsorption layer was also investigated. Additionally, the possibility of $\mathrm{Cr}(\mathrm{VI})$ reduction to non-toxic $\mathrm{Cr}(\mathrm{III})$ within the polymer-heavy metal ions complexes formed on the soil mineral surface was examined.

\section{Experimental}

\subsection{Materials and their characteristics}

Montmorillonite-2:1 aluminosilicate (Sigma-Aldrich) was used as an adsorbent in the experiments. Specific surface area and its porosity were determined using the nitrogen adsorption/desorption method (Micromeritics ASAP 2020 analyzer). The elemental composition of the mineral was determined by the XRF technique (Panalytical ED-XRF type Epsilon 3 spectrometer). Montmorillonite textural properties and elemental composition of the adsorbent were described in our previous paper (Wiśniewska et al. 2018). Using the high resolution scanning electron microscope Quanta 3D FEG (FEI, Field Electron and Ion Co.) the SEM images of clay mineral without or with the flocculant were obtained. To determine the possibility of intercalation 
process occurrence in montmorillonite after polymer addition the XRD technique was applied (diffractometer Empyrean, PANalytical).

Two types of polyacrylamide (Korona) differing in the ionic group contents were applied as the adsorbate in the study. The first one-anionic polyacrylamide (AN PAM) contained $30 \%$ of the ionizable carboxyl groups whereas the cationic polyacrylamide (CT PAM) $-35 \%$ of the quaternary amine groups. The average molecular weight of the adsorbate was equal to 13,000 and $7000 \mathrm{kDa}$, respectively. The dissociation degree of carboxyl groups in the PAM macromolecules was determined by means of the potentiometric titration method using the procedure presented in our previous papers (Wiśniewska et al. 2015, 2016). The detailed characteristics of the polymer samples are presented in Table 1.

\subsection{Spectrophotometric measurements}

The adsorption measurements were performed at $25{ }^{\circ} \mathrm{C}$ with the two solution $\mathrm{pH}$ values (neutral and slightly acidic conditions typical of clay soils), i.e. 5 and $7 \pm 0.1$. The sodium chloride $(\mathrm{NaCl})$ solution with the concentration of $0.001 \mathrm{~mol} / \mathrm{L}$ was used as a supporting electrolyte. Adsorbed amounts of polymer and heavy metal ion on the mineral surface were determined spectrophotometrically using the UV-Vis spectrophotometer (Carry 100; Varian) by the static method based on the difference between the PAM or $\mathrm{Cr}(\mathrm{VI})$ concentrations in the solutions before and after the adsorption. For determination of anionic polyacrylamide concentration in the solution the reaction of polyacrylamide with hyamine proposed by Crummet and Hummel (1963) was applied. It is based on the spectrophotometric measurements of absorbance generated by the PAM reaction with hyamine 1622 ( $N$-benzyl- $N, N$ dimethyl-2-\{2-[4-(2,4,4-trimethylpentan-2-yl)phenoxy] ethoxy \}ethanaminiumchloride). The absorbance originating from the white colour of solution, indicating PAMhyamine complex formation, was measured at the wavelength $500 \mathrm{~nm}$ after $15 \mathrm{~min}$ of the hyamine addition. The cationic polyacrylamide concentration was determined spectrophotometrically using the brilliant yellow as the indicator. After adjusting $\mathrm{pH} 9,0.5 \mathrm{ml}$ of the probe was added to $4.5 \mathrm{ml}$ of the indicator, and absorbance was measured at $495 \mathrm{~nm}$. In the case of chromium(VI), the reaction with diphenylcarbazide was used (Sas-Nowosielska 2009). In the acidic environment $\mathrm{Cr}(\mathrm{VI})$ oxidizes 1,5-diphenylcarbazide(I) to diphenylcarbazone(II) whereas it itself is reduced to $\mathrm{Cr}$ (III). The absorbance of the obtained purple complex between $\mathrm{Cr}$ (III) and diphenylcarbazone(II) was measured at a wavelength of $546 \mathrm{~nm}$ (Gardner and Comber 2002). Adsorption process was carried out under the conditions of continuous shaking (water bath OLS 200, Grant) for $24 \mathrm{~h}$. The montmorillonite weight in each examined system was $0.003 \mathrm{~g}$. The appropriate $\mathrm{pH}$ values of the examined suspensions were adjusted with a pH-meter (Beckman Instruments). The solids were centrifuged using a microcentrifuge (MPW Med. Instruments) and the clear solutions were collected for further analysis of polymer and $\mathrm{Cr}(\mathrm{VI})$ ion concentration.

The changes in the soil suspension stability without and with the polymer were monitored using the spectrophotometry (spectrophotometer Carry 1000, Varian). The absorbance of montmorillonite suspension with and without polyacrylamide was measured in a function of time at the wavelength $\lambda=500 \mathrm{~nm}$.

\subsection{Potentiometric titrations}

Using the potentiometric titration method surface charge density as a function of solution $\mathrm{pH}$ and point of zero charge (pzc) were determined. The potentiometric titrations of montmorillonite suspensions in the absence and presence of polyacrylamide and/or $\mathrm{Cr}(\mathrm{VI})$ were performed in the thermostated Teflon vessel using $0.1 \mathrm{~g}$ of the mineral. The solid surface charge density was calculated with the special program Titr_v3 (authored by Janusz 1994) using the following equation:

$\sigma_{0}=\frac{\Delta V \cdot c \cdot F}{m \cdot S}$

where $\Delta V$ - the difference in the base volume added to a suspension and a supporting electrolyte solution that leads to the specific $\mathrm{pH}$ value, $c$ - the base concentration, $F$ - the Faraday constant, $m$ - the solid mass in the suspension, $S$ the solid surface area. The measuring set was composed of the following parts: burette Dosimat 665 (Methrom), thermostat RE204 (Lauda), pH meter 71 (Beckman), computer and printer.
Table 1 The polyacrylamide samples characteristics

\begin{tabular}{llllllll}
\hline Symbol of polymer & $\begin{array}{l}\text { Weight average } \\
\text { molecular weight } \\
(\mathrm{kDa})\end{array}$ & $\begin{array}{l}\text { Ionic groups } \\
\text { content }(\%)\end{array}$ & $\mathrm{pK}$ & \multicolumn{4}{c}{ Dissociation degree (\%) at pH } \\
\cline { 5 - 8 } & 14,000 & 30 & 3.2 & 38.7 & 98.7 & 99.98 & 99.99 \\
AN PAM 30\% & 7000 & 35 & 9.3 & 99.99 & 99.99 & 99.44 & 64 \\
CT PAM 35\% & &
\end{tabular}


Fig. 1 SEM images of montmorillonite: a without PAM, $\mathbf{b}$ with AN PAM $30 \%$, c with CT PAM $35 \%$

\subsection{Spectroscopic measurements}

To determine the reduction process of $\mathrm{Cr}(\mathrm{VI})$ to $\mathrm{Cr}(\mathrm{III})$ occurring in the adsorption layer the Diffuse Reflectance Spectroscopy (DRS) was applied. After the adsorption process, the solid samples were centrifuged, dried and exposed to the IR beam in the course of DRS measurements. The DRS spectra were measured using the Jasco V-660 spectrometer equipped with a diffuse reflectance attachment PIV756 (Jasco, Japan). In order to separate the signals coming from various forms of chromium, the procedure of deconvolution of the obtained spectra was applied.

\section{Results and discussion}

\subsection{Adsorbent characteristic}

Specific surface area and porosity of montmorillonite were determined using a low-temperature nitrogen adsorption/ desorption method. The obtained results were presented in our previous paper (Wiśniewska et al. 2018). The specific surface area of the examined 2:1 type aluminosilicate is equal to $259 \mathrm{~m}^{2} / \mathrm{g}$. It is associated with the specific layered structure of this clay mineral. The observed isotherms of IV type with the $\mathrm{H} 3$ hysteresis loop indicate a multilayer adsorption on the mesopores (Anovitz and Cole 2015). Moreover, there are two groups of mesopores: the first of the average diameter equal to $3.8 \mathrm{~nm}$ and the other- $5.6 \mathrm{~nm}$. The pore volume of the soil mineral is about $0.37 \mathrm{~cm}^{3} / \mathrm{g}$.

The SEM images of montmorillonite with or without anionic/cationic polyacrylamide (Fig. 1) show the PAM adsorption effect on the mineral aggregation. Figure 1a presents highly dispersed solid particles without the polymer. Both the anionic and cationic PAM addition causes aggregation of solid particles but the flocks formed in the cationic soil flocculant presence are significantly larger.

\subsection{Stability studies}

The addition of polyacrylamide changes considerably the montmorillonite suspension stability (Fig. 2). In the case of CT PAM presence, the system shows small absorbance values after only $5 \mathrm{~min}$ from the beginning of measurements, which indicates formation of large flocks sedimenting easily on the bottom of the measuring vial. Thus, CT PAM exhibits flocculating properties with respect to the soil mineral
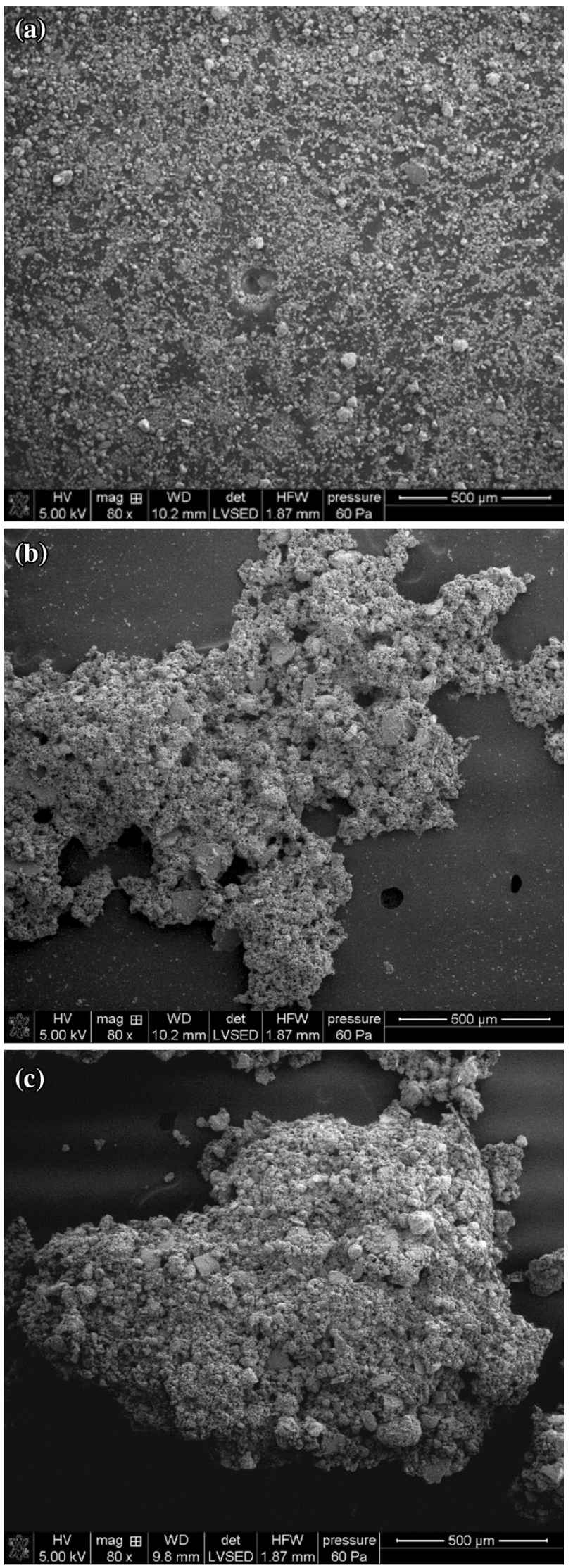
(a) 1.6

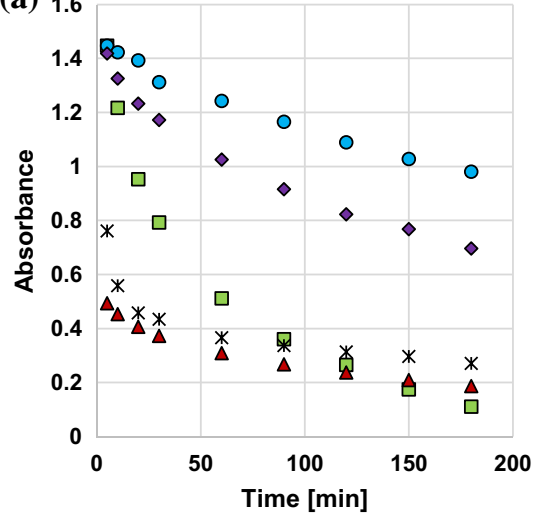

(b) 1 .

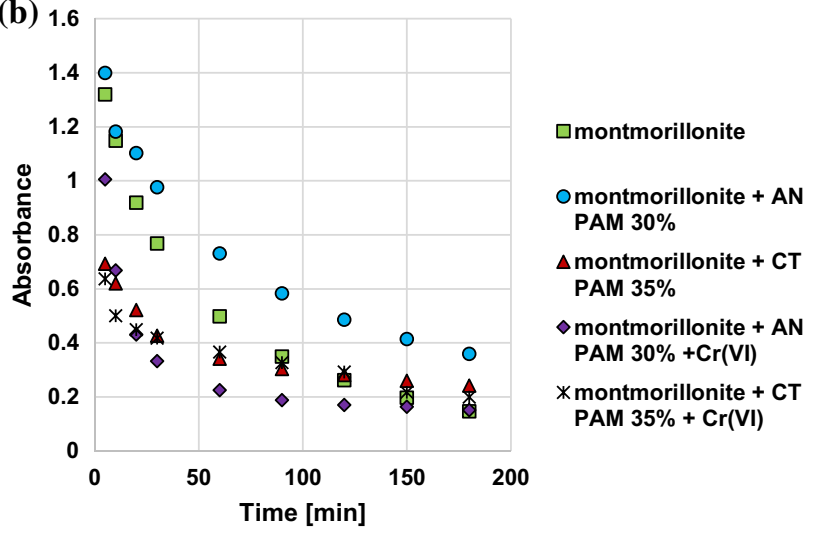

Fig. 2 Influence of ionic PAM addition on the montmorillonite suspension stability at: a $\mathrm{pH} \mathrm{5,} \mathrm{b} \mathrm{pH} \mathrm{7,} \mathrm{C}_{\mathrm{PAM}} 100 \mathrm{ppm}$

particles. The stability properties in systems containing CT PAM and $\mathrm{Cr}(\mathrm{VI})$ ions changes minimally (in comparison to suspensions without $\mathrm{Cr}(\mathrm{VI})$ ), both at $\mathrm{pH} 5$ and 7 .

In turn, in the anionic polymer presence the absorbance remains at a high level throughout the experiment (especially at $\mathrm{pH} 5$ ). At $\mathrm{pH} 5$ there is the point of zero charge of montmorillonite and adsorption of anionic polyacrylamide chains (whose carboxyl groups are totally dissociated, Table 1) can lead to electrosteric interactions between the solid particles covered with the AN PAM layers. But the greatest effect of montmorillonite suspension destabilization (among all examined systems) was obtained after addition of AN PAM and $\mathrm{Cr}(\mathrm{VI})$ ions at $\mathrm{pH} 7$.

\subsection{Adsorption of polyacrylamide and $\mathrm{Cr}(\mathrm{VI})$ on the montmorillonite surface}

The ionic polyacrylamide and $\mathrm{Cr}(\mathrm{VI})$ ions amounts adsorbed on the montmorillonite surface are presented in Figs. 3 and 4. These values depend largely on the solution $\mathrm{pH}$. The adsorbed amounts of cationic PAM increase with the $\mathrm{pH}$ decrease (higher adsorption of CT PAM is observed at $\mathrm{pH}$

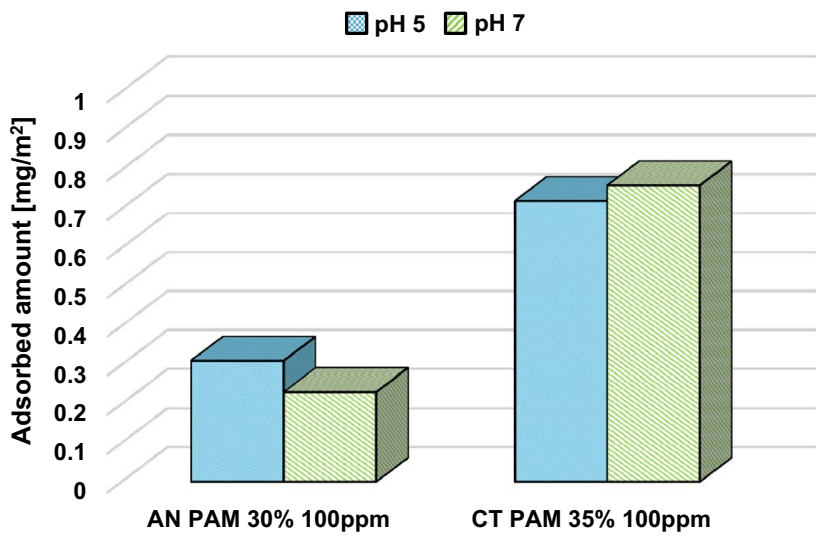

Fig. 3 Adsorbed amounts of AN PAM 30\% and CT PAM 35\% on the montmorillonite surface at $\mathrm{pH} 5$ and 7

7 than 5). The $\mathrm{pK}_{\mathrm{b}}$ value for the cationic polyacrylamide is 9.3. At $\mathrm{pH} 5$ and 7 the degree of quaternary amine groups dissociation in the polymer chains varies in the range of 99.4-99.9\%. Thus, all cationic groups of the polymer are present in the ionized form and they are a source of positive charge of adsorbing macromolecules. The higher adsorption affinity of CT PAM at pH 7 is due to favourable electrostatic attraction between the positively charged macromolecules and the negatively charged solid surface. In the case of anionic polyacrylamide, the adsorbed amount decreases with the increasing $\mathrm{pH}$. The $\mathrm{pK}_{\mathrm{a}}$ value of anionic PAM is equal to 3.2 and in the studied $\mathrm{pH}$ range the degree of carboxyl groups dissociation is from 98.7 to $99.8 \%$. Therefore smaller adsorption of AN PAM at pH 7 is caused by unfavorable electrostatic repulsion between the montmorillonite surface and the negatively charged ionized - $\mathrm{COOH}$ groups (present in macromolecules) and negatively charged solid surface. Under such electrostatic conditions adsorption of anionic polyacrylamide on the montmorillonite surface proceeds mainly through hydrogen bonds which are formed between the solid hydroxyl groups and the polymer functional groups

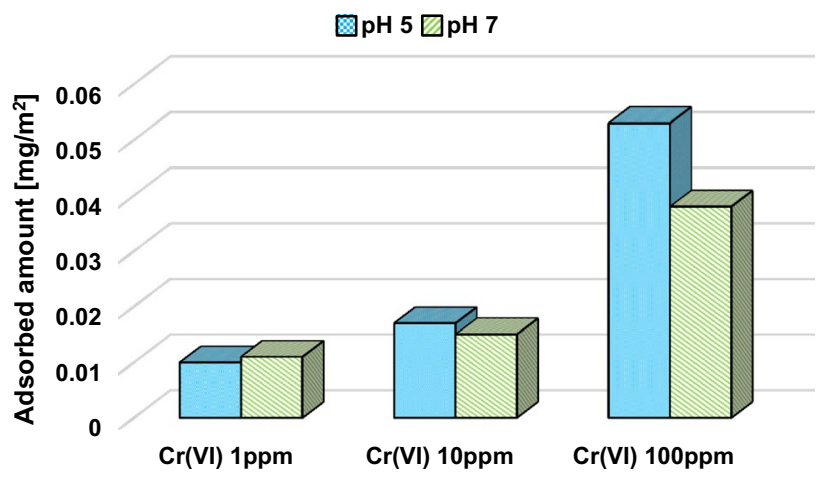

Fig. 4 Adsorbed amount of $\mathrm{Cr}(\mathrm{VI})$ ions on the montmorillonite surface at $\mathrm{pH} 5$ and 7 
(occurring both in the undissociated and dissociated forms). Moreover, polyacrylamide characterized by a higher content of cationic groups having a quaternary amine groups shows a noticeably higher adsorption level in comparison to the PAM containing ionizable carboxyl groups. At $\mathrm{pH}$ about 5 the total charge of montmorillonite surface is equal to zero (point of zero charge) and under such conditions the solid surface is neutral. For this reason at higher values of $\mathrm{pH}$ the electrostatic forces are more beneficial for the cationic polymer adsorption at $\mathrm{pH} 7$ whereas in the case of anionic polyacrylamide the adsorbed amount increases at $\mathrm{pH} 5$.

The adsorption of chromium(VI) ions decreases with the increasing $\mathrm{pH}$ value. These toxic metal ions occur in the forms of $\mathrm{CrO}_{4}{ }^{2-}$ and $\mathrm{HCrO}_{4}{ }^{-}$in the range of studied $\mathrm{pH}$ values. Therefore their affinity for the montmorillonite surface decreases with the increase of solid negative charge (similarly to negatively charged macromolecules of anionic polymer).

The polymer (and $\mathrm{Cr}(\mathrm{VI})$ ions) present in the montmorillonite system does not cause the changes in the crystal structure of montmorillonite. The ionic polyacrylamide chains are probably too large to penetrate the space between the silica and alumina sheets of solid mineral and the intercalation process does not take place. Such behaviour was confirmed by XRD measurements. The analysis of their results indicated only minimal changes in basal spacing $\mathrm{d}_{001}$ (Frost and Rintoul 1996; Krupskaya et al. 2017), obtained at values of $2 \theta$ angle changing in the range $6-6.5$, for the montmorillonite particles modified with ionic polyacrylamide and $\mathrm{Cr}(\mathrm{VI})$ ions (Table 2) in comparison to the unmodified solid.

\subsection{Effects of $\mathrm{Cr}(\mathrm{VI})$ concentration on the polyacrylamide adsorbed amount on the montmorillonite surface}

As can be seen in Fig. 5 in the systems of mixed adsorbates, the $\mathrm{Cr}(\mathrm{VI})$ ions concentration has a minimal effect on the cationic polyacrylamide adsorption. In the case of AN PAM 30\% the addition of $\mathrm{Cr}(\mathrm{VI})$ ions of the concentration $1 \mathrm{ppm}$ evidently increases the adsorption level of ionic polyacrylamide whereas the presence of chromium(VI) ions of the concentrations of 10 and $100 \mathrm{ppm}$ does not affect

Table 2 Basal spacing $\mathrm{d}_{001}$ values in the montmorillonite structure obtained from XRD measurements

\begin{tabular}{ll}
\hline System & $\mathrm{d}_{001}(\AA)$ \\
\hline Montmorillonite & 14.92 \\
Montmorillonite/AN PAM 30\% & 13.47 \\
Montmorillonite/CT PAM 35\% & 14.54 \\
Montmorillonite/AN PAM 30\%/Cr(VI) & 13.41 \\
Montmorillonite/CT PAM 35\%/Cr(VI) & 14.42 \\
\hline
\end{tabular}
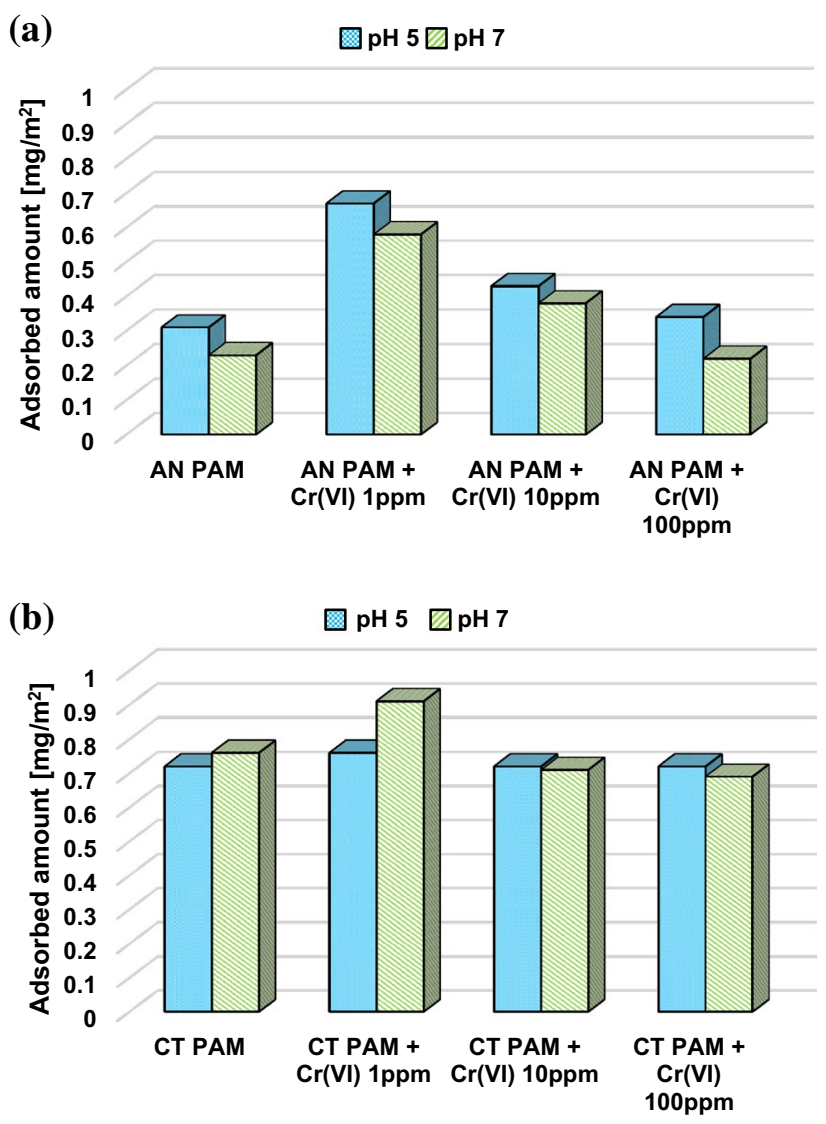

Fig. 5 Adsorbed amounts of: a AN PAM 30\%, b CT PAM 35\% on the montmorillonite surface at $\mathrm{pH} 5$ and 7 in the presence of $\mathrm{Cr}(\mathrm{VI})$ ions with different concentrations; both adsorbates were added at the same time, $\mathrm{C}_{\text {PAM }} 100 \mathrm{ppm}$

the amount of adsorbed AN PAM $30 \%$. Such behaviour is associated with creation of hydrogen bonds between the PAM neutral amide groups and $\mathrm{CrO}_{4}{ }^{2-}$ and $\mathrm{HCrO}_{4}{ }^{-}$ions (Bajpai and Johnson 2007; Zhang et al. 2012). Consequently, the polymeric macromolecules assume the specific conformation at the solid/liquid interface which directly determines the polymer adsorbed amount.

On the other hand, the cationic polyacrylamide has a strongly developed conformation due to the presence of positively charged groups in the $\mathrm{pH}$ range 5-7. Due to the electrostatic attraction between the $\mathrm{CrO}_{4}{ }^{2-}$ and $\mathrm{HCrO}_{4}{ }^{-}$anions and the cationic polymer quaternary amine groups, as well as formation of hydrogen bonds between the PAM amide functional groups and chromium(VI) ions, a slight increase in the adsorbed amount of cationic polyacrylamide in the presence of toxic metal ions is observed (Bajpai and Johnson 2007; Zhang et al. 2012). The schematic representation of adsorption mechanism of PAM$\mathrm{Cr}(\mathrm{VI})$ complexes on the montmorillonite surface was presented in Fig. 6. 


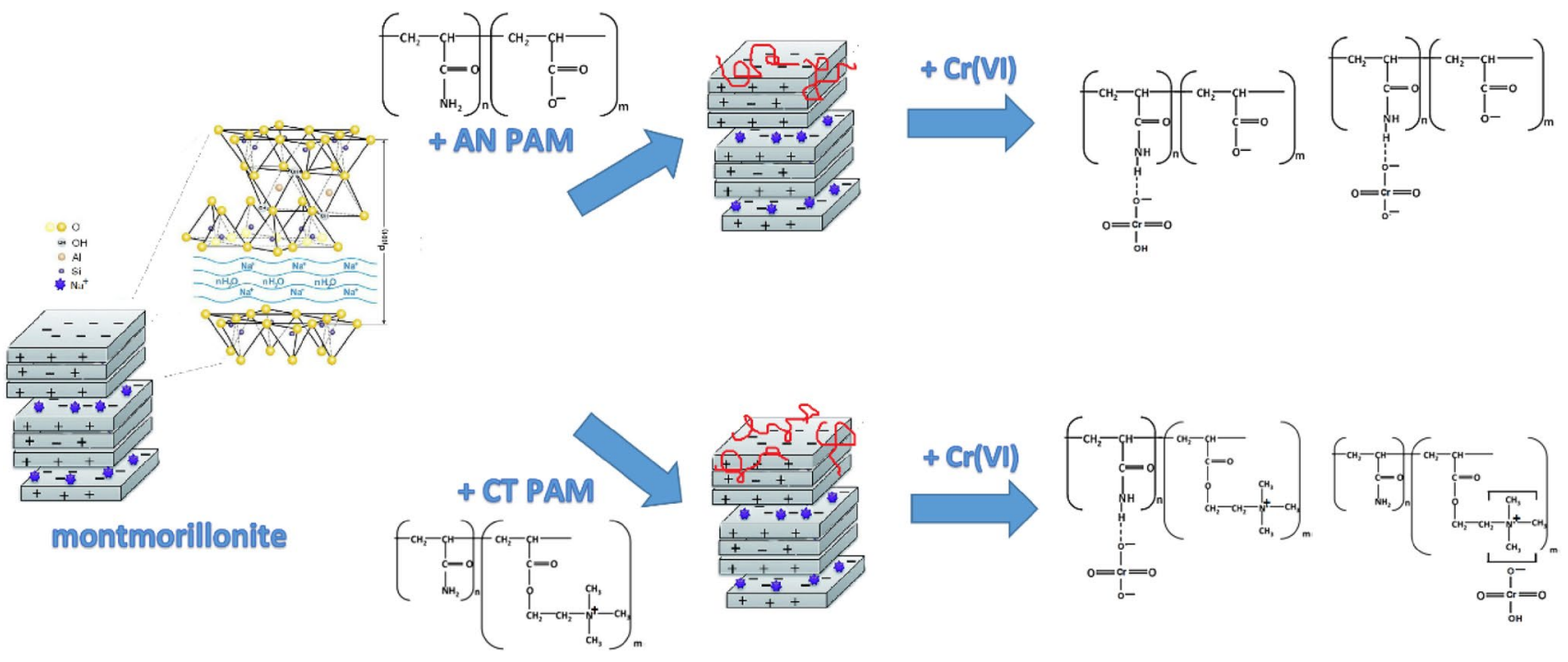

Fig. 6 The schematic representation of adsorption mechanism of PAM-Cr(VI) complexes on the montmorillonite surface (schema of montmorillonite structure: http://www.bentonites.net, Ubowska 2010)

\subsection{Influence of $\mathrm{PAM}$ presence and $\mathrm{Cr}(\mathrm{VI})$ concentration on the $\mathrm{Cr}(\mathrm{VI})$ adsorbed amount on the montmorillonite surface}

At the lowest examined $\mathrm{Cr}(\mathrm{VI})$ ions concentration (i.e. $1 \mathrm{ppm})$, both anionic and cationic polyacrylamide presence does not affect the adsorption amount of heavy metal ions (Fig. 7a, b). In this case all chromium(VI) ions undergo adsorption on the solid surface. However, with the increase of $\mathrm{Cr}(\mathrm{VI})$ ions concentration in the solution, its adsorption in the PAM presence also increases. In the system with the $\mathrm{Cr}(\mathrm{VI})$ ions concentration equal to $100 \mathrm{ppm}$ the adsorption of these toxic metal ions in the presence of both ionic forms of PAM is over twice higher in comparison to the system without polymer. The CT PAM chains are endowed with a positive charge in the investigated $\mathrm{pH}$ range, which promotes adsorption of negatively charged chromium(VI) anions. On the other hand, the anionic polyacrylamide adsorbed on the montmorillonite surface captures $\mathrm{CrO}_{4}{ }^{2-}$ and $\mathrm{HCrO}_{4}{ }^{-}$ions from the solution effectively through hydrogen bond creation. As a consequence, a significant increase in the $\mathrm{Cr}(\mathrm{VI})$ ions adsorption is observed in the ionic polyacrylamide presence.

\subsection{Electrokinetic properties of montmorillonite particles without and with polyacrylamide and $\mathrm{Cr}(\mathrm{VI})$}

Table 3 shows the $\mathrm{pH}_{\mathrm{pzc}}$ of the examined systems. At $\mathrm{pH}$ 5.02 the total charge of montmorillonite surface is equal to zero-the concentration of the positively $\left(-\mathrm{SiOH}_{2}{ }^{+}\right)$ and negatively $\left(-\mathrm{SiO}^{-}\right)$charged surface groups is the (a)

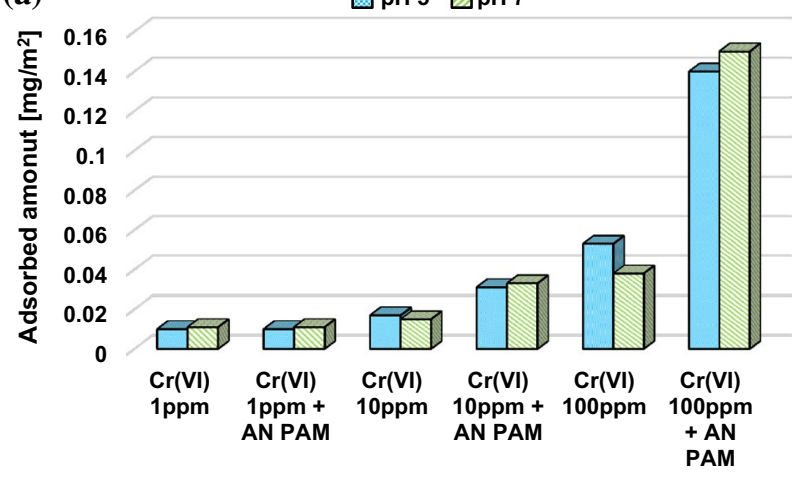

(b)

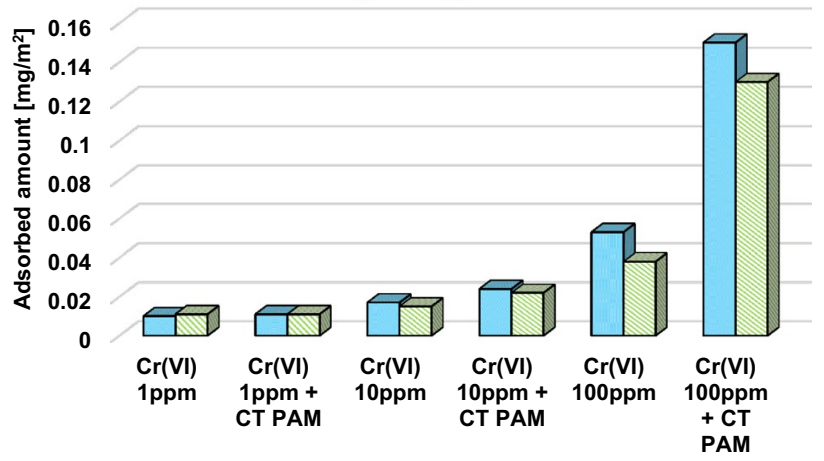

Fig. 7 Adsorbed amounts of $\mathrm{Cr}(\mathrm{VI})$ ions on the montmorillonite surface at $\mathrm{pH} 5$ and 7 in the presence of $\mathbf{a}$ anionic PAM, b cationic PAM; both adsorbates were added at the same time, $\mathrm{C}_{\mathrm{PAM}} 100 \mathrm{ppm}$ 
Table 3 The $\mathrm{pH}_{\mathrm{pzc}}$ values of examined systems

\begin{tabular}{lc}
\hline System & $\mathrm{pH}_{\mathrm{pzc}}$ \\
\hline Montmorillonite & 5.02 \\
Montmorillonite/AN PAM 30\% & 4.93 \\
Montmorillonite/CT PAM 35\% & 5.47 \\
Montmorillonite/Cr(VI) & 6.11 \\
Montmorillonite/AN PAM 30\%/Cr(VI) & 5.44 \\
Montmorillonite/CT PAM 35\%/Cr(VI) & 5.36 \\
\hline
\end{tabular}

same (pzc conditions). At $\mathrm{pH}$ values lower than $\mathrm{pH}_{\mathrm{pzc}}$ the solid surface is positively charged and above the $\mathrm{pH}_{\mathrm{pzc}}$ value-negatively charged. The CT PAM addition causes the increase of the solid surface charge density compared to the system without the polymer. Besides the unionizable amide groups cationic polyacrylamide contains $35 \%$ of quaternary amine groups which are a source of positive charge of the polymer chains. Under the examined $\mathrm{pH}$ conditions positively charged groups are very numerous and their adsorption on the mineral surface causes a significant increase of its surface charge density. However, only a part of $-\mathrm{N}\left(\mathrm{CH}_{3}\right)_{3}{ }^{+}$groups is located directly on the solid surface when most of them are placed in the by-surface layer of the solution in the tail and loop structures of the adsorbed macromolecules causing an increase of $\mathrm{pH}_{\mathrm{pzc}}$ value. In the case of AN PAM/montmorillonite system the addition of anionic polymer causes a decrease of the solid surface charge density. The increase in the solution $\mathrm{pH}$ results in the complete dissociation of polymeric macromolecules and their negatively charged $-\mathrm{COO}^{-}$groups (mostly placed in the by-surface layer of the solution) cause a decrease of $\sigma_{0}$ and $\mathrm{pH}_{\mathrm{pzc}}$ values.

The chromium(VI) ions adsorption on the montmorillonite surface causes shift of $\mathrm{pH}_{\mathrm{pzc}}$ to the value of about 6.5. Increase of this parameter is common behaviour observed in the case of small anion adsorption (such as chromium(VI) anions). Their interactions with the solid hydroxyl groups result in creation of the additional number of positively charged surface sites and the $\sigma_{0}$ value increases (Janusz 1999; Wiśniewska et al. 2017). In the adsorption systems containing CT PAM and $\mathrm{Cr}(\mathrm{VI})$ the montmorillonite $\mathrm{pH}_{\mathrm{pzc}}$ parameter is similar to that of the polymer containing system. Thus, it can be stated that the polymer-metal complexes present in the interfacial layer assume such spatial arrangement that the chromium(VI) ions present in their structure cause only insignificant changes in the surface charge of the investigated mineral. In the case of AN PAM 30\%, the increase of solid surface charge of the mixed system in comparison to the simple one (hydrogen bonds are formed between chromate anions and amide groups of polymer increasing the negative charge of PAM macromolecules) is observed (Bajpai and Johnson 2007; Zhang et al. 2012).
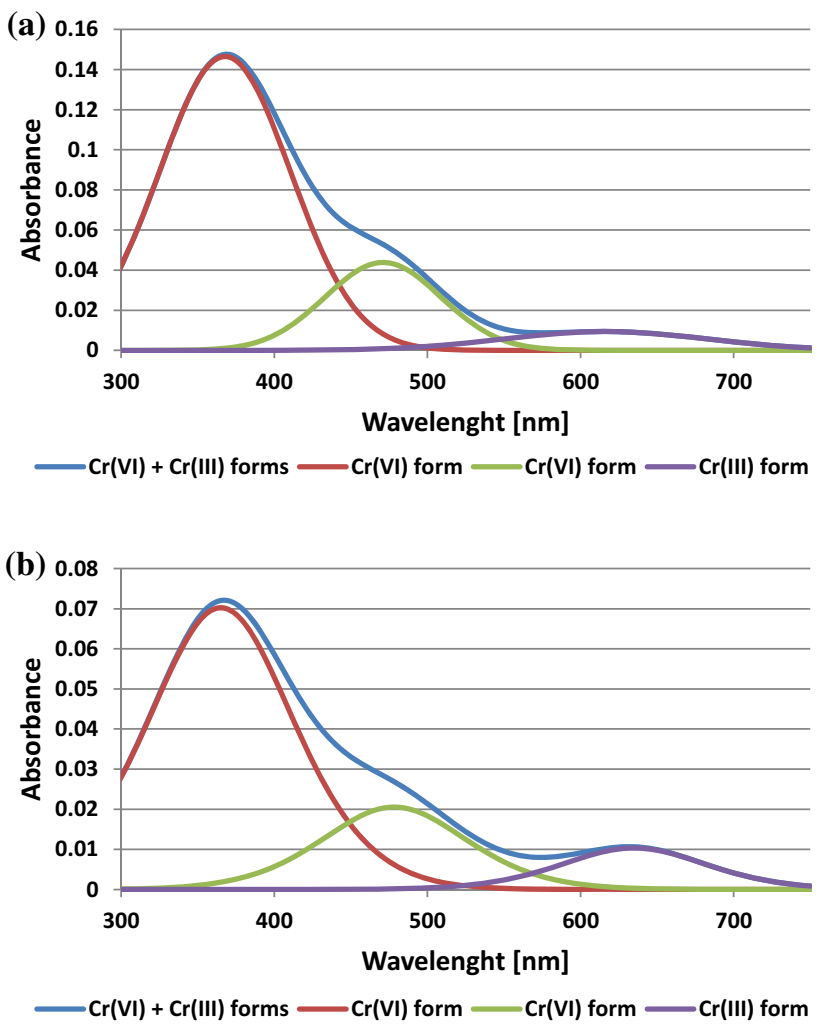

Fig. 8 DRS spectra obtained in the systems: a montmorillonite-AN PAM-Cr(VI), b montmorillonite-CT PAM-Cr(VI)

\subsection{Reduction of $\mathrm{Cr}(\mathrm{VI})$ to $\mathrm{Cr}$ (III) in the montmorillonite-PAM system}

Diffuse reflectance spectroscopy (DRS) allows identification of both chromium forms (on both the III and VI oxidation degrees) after their sorption in the montmorillonite-PAM system. Figure $8 \mathrm{a}$ and $\mathrm{b}$ presents obtained DRS spectra for the examined AN PAM and CT PAM containing systems, respectively. The region of DRS spectra related to the chromium(III) form is at $620 \mathrm{~nm}$. The signals below $550 \mathrm{~nm}$ are due to the presence of chromium(VI). It can be concluded that chromium(VI) bound with ionic polyacrylamide in the adsorption layer on the montmorillonite surface undergoes reduction to the chromium(III) form. Free electron pairs located on the nitrogen atoms of PAM amide groups are probably involved in this process. This is a very desirable phenomenon due to non-toxic properties of chromium(III) form compared to chromium(VI) one.

\section{Conclusions}

Based on the obtained results there can be drawn the following conclusions: 
(1) Higher adsorption of polyacrylamide on the montmorillonite surface is observed in the case of the polymer with a quaternary amine groups due to the more favourable electrostatic attraction occurring between the positively charged macromolecules and the negatively charged surface of montmorillonite.

(2) A larger amount of chromium(VI) ions is adsorbed at $\mathrm{pH} 5$ because with the $\mathrm{pH}$ increase there are more and more negatively charged groups on the surface of aluminosilicate which is not favourable for the adsorption of chromium(VI) anions.

(3) Anionic and cationic PAM captures $\mathrm{CrO}_{4}{ }^{2-}$ and $\mathrm{HCrO}_{4}^{-}$ions effectively from the solution by electrostatic attraction between the chromium(VI) anion and the cationic polymer quaternary amine groups as well as formation of hydrogen bonds between the PAM amide groups and the chromium(VI) ions which contributes to a significant increase in their adsorption.

(4) The presence of chromium(VI) ions and ionic polyacrylamide affects montmorillonite electrokinetic properties.

(5) Both anionic and cationic polyacrylamide flocculants adsorbed on the montmorillonite particles can cumulate heavy metal ions.

(6) In the examined montmorillonite-PAM-Cr systems there is observed the process of reduction of $\mathrm{Cr}(\mathrm{VI})$ to $\mathrm{Cr}$ (III) which is beneficial for the environment due to non-toxic properties of chromium(III).

Open Access This article is distributed under the terms of the Creative Commons Attribution 4.0 International License (http://creativeco mmons.org/licenses/by/4.0/), which permits unrestricted use, distribution, and reproduction in any medium, provided you give appropriate credit to the original author(s) and the source, provide a link to the Creative Commons license, and indicate if changes were made.

\section{References}

Ajwa, H.A., Trout, T.J.: Polyacrylamide and water quality effects on infiltration in sandy loam soils. Soil Sci. Soc. Am. J. 70, 643-650 (2006)

Anovitz, L.M., Cole, D.R.: Characterization and analysis of porosity and pore structure. Rev. Min. Geochem. 80, 161-164 (2015)

Bajpai, S.K., Johnson, S.: Removal of Cr(VI) oxy-anions from aqueous solution by sorption into poly(acrylamide-co-maleic acid) hydrogels. Sep. Pur. Technol. 42, 1049-1064 (2007)

Basaran, H.K., Tasdemir, T.: Determination of flocculation characteristics of natural stone powder suspensions in the presence of different polymers. Physicochem. Probl. Miner. Proc. 50, 69-84 (2014)

Ben-Hur, M., Keren, R.: Polymer effects on water infiltration and soil aggregation. Soil Sci. Soci. Am. J. 61, 565-570 (1997)

Bronick, C.J., Lal, R.: Soil structure and management: a review. Geoderma 124, 3-22 (2005)
Crummett, W.B., Hummel, R.A.: The determination of traces of polyacrylamides in water. J. Am. Water Works Assoc. 1, 209-219 (1963)

Deng, Y., Dixon, J.B., White, G.N.: Adsorption of polyacrylamide on smectite, illite, and kaolinite. Soil Sci. Soci. Am. J. 70, 297-304 (2006)

Devi, M., Fingermann, M.: Inhibition of acetylcholinesterase activity in the central nervous system of the red swamp crayfish, procambarus clarkia, by mercury, cadmium and lead. Bull. Environ. Contam. Toxicol. 55, 746-750 (1995)

Frost, R.L., Rintoul, L.: Lattice vibration of montmorillonite: an FT Raman and X-ray diffraction study. Appl Clay Sci. 11, 171-183 (1996)

Gardner, M., Comber, S.: Determination of trace concentrations of hexavalent chromium. Analyst 127, 153-156 (2002)

Graveling, G.J., Ragnarsdottiv, K.V., Allen, G.C., Eastman, J., Brady, P.V., Balsley, S.D., Skuse, D.R.: Controls on polyacrylamide adsorption to quartz, kaolinite, and feldspar. Geochim. Cosmochim. Acta 61, 3515-3523 (1997)

Green, V.S., Scott, D.E., Graveel, J.G., Norton, L.D.: Stability analysis of soil aggregates treated with anionic polyacrylamides of different molecular formulations. Soil Sci. 169, 573-581 (2004)

Grochowski, M., Nosal-Wiercińska, A., Wiśniewska, M., Szabelska, A., Gołębiowska, B.: The effects of homocysteine protonation on double layer parameters at the electrode/chlorates (VII) interface, as well as the kinetics and the mechanism of $\mathrm{Bi}$ (III) ion electroreduction. Elecrochim. Acta 207, 48-57 (2016)

Guezennec, A.G., Michel, C., Bru, K., Touze, S., Desroche, N., Mnif, I., Motelica-Heino, M.: Transfer and degradation of polyacrylamide based flocculants in hydrosystems: a review. Environ. Sci. Pollut. Res. 22(9), 6390-6406 (2015)

Hadjispyrou, S., Kungolos, A., Anagnostopoulos, A.: Toxicity, bioaccumulation and interactive effects of organofin, cadmium, and chromium on Artemia franciscana. Ecotoxicol. Environ. Saf. 49, 179-186 (2001)

Handke, M.: Krystalochemia krzemianów. Uczelnianie Wydawnictwo Naukowo-Dydaktyczne, Kraków (2005)

He, J., Chu, J., Tan, S.K., Vu, T.T., Lam, K.P.: Sedimentation behavior of flocculant-treated soil slurry. Mar. Geores. Geotechnol. 35, 593-602 (2017)

Janusz, W.: Electrical double layer at the metal oxide/electrolyte interface in interfacial forces and fields: theory and applications in Surfactant science, chap. 4, vol. 85, Marcel Decker, New York (1994)

Janusz, W.: Electrical double layer at the metal oxide/electrolyte interface, in 'interfacial forces and fields: theory and applications. M. Dekker, New York (1999)

Kacperski, M.: Polymer nanocomposites. Part I. General characteristics, fillers and nanocomposites based on termosetting polymers. Polimery 47, 801-807 (2002)

Karthikeyan, T., Rajgopal, S., Miranda, I.R.: Chromium(VI) adsorption from aqueous solution by Hevea brasilinesis sawdust activated carbon. J. Hazard. Mater. 124, 192-199 (2005)

Kowalski, Z.: Treatment of chromic tannery wastes. J. Hazard. Mater. 37, 137-144 (1994)

Krupskaya, V.V., Zakusin, S.V., Tyupina, E.A., Dorzhieva, O.V., Zhukhlistov, A.P., Belousov, P.E., Timofeeva, M.N.: Experimental study of montmorillonite structure and transformation of its properties under treatment with inorganic acid solutions. Minerals 7, 49 (2017)

Kunert, A., Zaborski, M.: The structure, properties and uses of layered minerals. Przem. Chem. 85, 1510-1517 (2006)

Kurleto, Ż, Grabowska, B., Kaczmarska, K., Szymański, Ł: Wiązania chemiczne występujące w montmorylonicie. Archiv. Found. Eng. 15, 77-92 (2015) 
Lee, B.J., Schlautman, M.A.: Effects of polymer molecular weight on adsorption and flocculation in aqueous kaolinite suspensions dosed with nonionic polyacrylamides. Water 7, 5896-5909 (2015)

Lee, S.S., Chang, S.X., Chang, Y.Y., Ok, Y.S.: Commercial versus synthesized polymers for soil erosion control and growth of Chinese cabbage. SpringerPlus 2, 1-10 (2013)

Lee, C.S., Robinson, J., Chong, M.F.: A review on application of flocculants in wastewater treatment. Proc. Saf. Environ. Protect. 92 , 489-508 (2014)

Mamedov, A.J., Wagner, L.E., Huang, C., Norton, L.D., Levy, G.J.: Polyacrylamide effects on aggregate and structure stability of soils with different clay mineralogy. Soil Sci. Soc. Am. J. 74, $1-12$ (2010)

Mclaughlin, R.A., Bartholomew, N.: Soil factors influencing suspended sediment flocculantion by polyacrylamide. Soil Sci. Am. J. 71, 537-544 (2007)

Mikuła, J., Łach, M.: Potencjalne zastosowania glinokrzemianów pochodzenia wulkanicznego. Mechanika Czasopismo Techniczne 109, 109-122 (2002)

Natkański, P., Białas, A., Kuśtowski, P.: Synteza kompozytów poli(kwas akrylowy)-bentonit oraz poliakryloamid-bentonit do zastosowań adsorpcyjnych. Chemik 66, 742-749 (2012)

Nosal-Wiercińska, A.: Intermolecular interactions in systems containing $\mathrm{Bi}(\mathrm{III})-\mathrm{ClO}_{4}^{-} \mathrm{H}_{2} \mathrm{O}$ - selected amino acids in the aspect of catalysis of $\mathrm{Bi}(\mathrm{III})$ electroreduction. Electroanalysis 26, 10131023 (2014)

Nosal-Wiercińska, A., Dalmata, G.: Studies of the effect of thiourea on the electroreduction of In(III) ions in perchloric acid. Electroanalysis 14, 1275-1280 (2002)

Ociepa-Kubicka, A., Ociepa, E.: Toksyczne oddziaływanie metali ciężkich na rośliny, zwierzęta i ludzi. Inżynieria i Ochrona Środowiska 15, 169-180 (2012)

Olejnik, M.: Polymer nano-composites with montmorillonyte - obtaining, assesment methods, properties and applications. Techniczne Wyroby Włókiennicze 16, 67-74 (2008)

Pueyo, M., Lopez-Sanchez, J.F., Rauret, G.: Assessment of $\mathrm{CaCl}_{2}$, $\mathrm{NaNO}_{3}$, and $\mathrm{NH}_{4} \mathrm{NO}_{3}$ extraction procedures for the study of $\mathrm{Cd}$, $\mathrm{Cu}, \mathrm{Pb}$ and $\mathrm{Zn}$ extractability in contaminated soils. Anal. Chim. Acta 504, 217-225 (2004)

Quek, S.Y., Wase, D.A.J., Forster, C.F.: The use of Sago waste for the adsorption of lead and copper. Water S. A. 24(3), 251 (1998)

Sarbak, Z.: Nieorganiczne materiały nanoporowate. Wydawnictwo Naukowe UAM, Poznań (2009)

Sarbak, Z.: Application of sorbents in the process of soil remediation. Chemistry-Didactics-Ecology-Metrology 15, 77-92 (2010)

Sas-Nowosielska, A.: Fitotechnologie w remediacji terenów zanieczyszczonych przez przemysł cynkowo-ołowiowy, Monografia nr 189. Wyd. Politechniki Częstochowskiej, Częstochowa (2009)

Sojka, R.E., Bjorneberg, D.L., Entry, J.A., Lentz, R.D., Orts, W.J.: Polyacrylamide in agriculture and environmental land management. Agronomy 92, 75-162 (2007)
Stearns, D.M., Kennedy, L.J., Courtney, K.D., Giangrande, P.H., Phieffer, L.S., Wetterhahn, K.E.: Reduction of chromium (VI) by ascorbate leads to chromium-DNA binding and DNA strand breaks in vitro. Biochemistry 34, 910 (1995)

Szymański, K.: Związki ołowiu i chromu w środowisku naturalnym i odpadach. Rocznik Ochrona Środowiska 11, 173-181 (2009)

Ubowska, A.: Montmorillonite as a polyurethane foams flame retardant. Archiv. Combust. 30, 459-462 (2010)

Uddin, F.: Clays, nanoclays, and montmorillonite minerals. Metall. Mater. Trans. A 39, 2804-2814 (2008)

Uddin, M.K.: A review on the adsorption of heavy metals by clay minerals, with special focus on the past decade. Chem. Eng. J. 308, 438-462 (2017)

Vasquez-Murrieta, M.S., Migules-Garduno, I., Franco-Hernandez, O., Govaerts, B., Dendooven, L.: C and N mineralization and microbial biomass in heavy-metal contaminated soil. Eur. J. Soil Biol. 42, 89-98 (2006)

Wang, Q., Cui, Y., Liu, X., Dong, Y., Christie, P.: Soil contamination and plant uptake of heavy metals at polluted sites in China. J. Environ. Sci. Health A 38, 823-838 (2003)

Wang, Z., Zhang, H., Pan, G.: Ecotoxicological assessment of flocculant modified soil for lake restoration using integrated biotic toxicity index. Water Res. 97, 133-141 (2016)

Wiśniewska, M., Chibowski, S., Urban, T.: Impact of polyacrylamide with different contents of carboxyl groups on the chromium(III) oxide adsorption properties in aqueous solution. J. Hazard. Mater. 283, 815-823 (2015)

Wiśniewska, M., Chibowski, S., Urban, T.: Nanozirconia surface modification by anionic polyacrylamide in relation to the solid suspension stability - effect of anionic surfactant addition. Powder Technol. 302, 357-362 (2016)

Wiśniewska, M., Chibowski, S., Urban, T.: Comparison of adsorption affinity of ionic polyacrylamide for the surfaces of selected metal oxides. Adsorp. Sci. Technol. 35, 582-591 (2017)

Wiśniewska, M., Fijałkowska, G., Szewczuk-Karpisz, K.: The mechanism of anionic polyacrylamide adsorption on the montmorillonite surface in the presence of $\mathrm{Cr}(\mathrm{VI})$ ions. Chemosphere 211, 524-534 (2018)

Wójcik, W., Odum, H.T., Szilder, Ł: Ołów i cynk w środowisku oraz rola mokradeł w ich usuwaniu. Uczelniane Wydawnictwa Naukowo-Dydaktyczne, Kraków (2004)

Zhang, D., Ma, Y., Feng, H., Hao, Y.: Adsorption of Cr(VI) from aqueous solution using carbon-microsilica composite adsorbent. J. Chil. Chem. Soc. 57, 964-968 (2012)

Zhu, R., Chen, Q., Zhou, Q., Xi, Y., Zhu, J., He, H.: Adsorbents based on montmorillonite for contaminant removal from water: a review. Appl. Clay Sci. 123, 239-258 (2016) 